\title{
Social bonds as a tool for financing concession projects in the housing and communal services sector in Rostov oblast, Russia
}

\author{
Elena Sidorenko* \\ Don State Technical University, 344002, Rostov-on-Don, Russia
}

\begin{abstract}
The article discusses the possibility of using social bonds as the additional sources of financing in the construction and operation of water supply and sanitation facilities under concession agreements. The specifics of social bonds in accordance with the requirements of the International Capital Markets Association (ICMA) to social impact projects has been clarified. It is proposed to use the social bonds' circulation mechanism in the implementation of investment projects for the technological modernization of water supply and sewerage networks in the municipalities of the Rostov region. The liquidity of social bonds will be determined by collateral, which will be the government grants, which the investor will be able to receive only if the stated social goals are achieved. In order to reduce risks and increase the attractiveness of social impact projects, it is proposed to use the RR Regional Development Corporation as a project operator and guarantee fund.
\end{abstract}

\section{Introduction}

The need for technological renewal of industrial and social infrastructure has led to the use of public-private partnerships (PPPs), designed to create an effective mechanism for the construction and operation of large infrastructure facilities on the basis of pooling the resources of the private sector and public authorities. In this regard, it is important to ensure funding for such projects from various sources. In this study, it is proposed to consider the possibility of using such a debt instrument as social bonds in the field of housing and communal services (HCS) in the region.

World practice proposes to link the solution of economic goals with the tasks of social development of territories, for which the International Capital Markets Association (ICMA) has developed principles and recommendations for the development of debt instruments for financing projects aimed at solving significant social problems. Social bonds are securities, the funds from the placement of which are directed to the implementation of projects that allow achieving specific positive changes. The principles of social bonds are focused on universalizing the market for these bonds by introducing transparency in all project information. They should stimulate the growth of investment in social projects, without any intermediaries.

\footnotetext{
*Corresponding author: ataka_s11@mail.ru
} 
This problem is being actively developed by the scientific community. Prospects for PPP involvement in production infrastructure modernization are widely studied Kovriginoy S.V., Kozlovoy S.V., Petyukova S.E. [6, 7, 10].

Kalinin N.V., Medvedeva T.V., Romitsyna G.A., Hulukshinov D.E., Sidorenko E.N. consider the possibility of introducing infrastructure bonds and other payment instruments into the domestic practice of PPP relations [5, 13, 14].

Issues of expanding the investment sources in concessions and PPP -the projects through the use of social bonds are analyzed by such scientists as Ivanova N.V., Kryukova K.I., Petrosyan A.A., Chernyshova M.V., Naumova L.V. [3, 8, 9].

However, due to the fact that the practice of social bonds in Russia is still emerging, the regulatory and other institutional conditions are still at the stage of finalization, the possibilities of their application in public-private partnerships require deeper analysis and generalization. The development of social bonds will make it possible to more closely link the socio-economic development of territories and financial mechanisms for long-term investment PPP-projects. The purpose of this article is to study the prospects for using social bonds as an additional financing instrument in concession and PPP projects for the HCS infrastructure facilities modernization. To achieve the goal, the following tasks have been set:

- To find out the features of social bonds in financing technological modernization of facilities HCS with in the framework of public-private partnership;

- To consider the system of interaction of all participants in social impact projects in the field of water supply and sanitation using the example of the Rostov region;

- To substantiate the need to create a guarantee fund for the implementation of social impact projects in order to further protect the investor and increase the investment concessions attractiveness in HCS.

- To develop recommendations for the social bonds' implementation in concession projects in the Rostov region.

\section{Materials and Methods}

The theoretical and methodological basis of the study was the works of domestic and foreign scientists in the field of investment in industrial infrastructure, clarification of the specifics of financing PPP-projects through debt instruments. The information base of the study was composed of analytical reviews of the National Center for Public-Private Partnerships, data from domestic statistics, the website of the International Association of Capital Markets (ICMA).

The article uses the method of comparative analysis, an integrated approach, a hypothesis is put forward that social bonds, under certain conditions, can become an additional source of financing for large investment projects in the field of HCS with in the framework of concession projects, while ensuring the solution of the social goals of the region. When analyzing the prospects for the circulation of social bonds, we used the assessments of specialists from the National Center for Public-Private Partnerships, the Expert Council on the Long-Term Investment Market at the Bank of Russia [9] and the International Association of Capital Markets (ICMA).

\section{Results and Discussions}

Social bonds are a debt instrument, the proceeds from the placement of which are directed to the full or partial financing of new or existing social projects that comply with the principles of social bonds. These bonds are designed to solve social problems while saving 
public funds. Moreover, their emission and circulation must comply with a number of principles. We are talking about the obligatory use of funds from the placement of these bonds for the development of society, about special criteria for the selection of projects of social impact and assessment of social effect, requirements for disclosure of information and its transparency.

Projects under consideration should be aimed at solving or mitigating a specific social problem or at achieving positive social outcomes that need to be quantified. In the project, it is advisable to determine the target group, the so-called social beneficiaries, for whom the implemented project will improve their well-being. Bond payments are made by the government if the investor achieves fixed social goals. If the goals are not met, the income is not paid.

There are currently four types of social bonds:

- standard promissory note with the right to claim against the issuer;

- income-linked social bonds, where the collateral can be future cash receipts, etc.;

- social bonds of project financing, the investor under which bears only the associated risks of the project;

- securitized social bonds secured by one or more social projects, the main repayment source of which is cash receipts from assets.

In Russia, the use of social bonds is regulated by the Government Decree "On the social impact projects pilot testing organization by the constituent entities of the Russian Federation in 2019-2024". VEB. RF is the operator of all such projects [11].

The interaction of the parties within the framework of these social projects can be described as follows: the organizer implements a project aimed at improving the life of a certain category of the population, at his own expense. The project can be carried out independently or by engaging third-party organizations. The regional government coordinates with the private party the project passport, which reflects the target indicator of social effect, and the amount of the grant that the investor will receive after confirming the achievement of this social indicator. Then a regulatory document on the project implementation is approved, an agreement on the provision of a grant is concluded, a project operator is allocated, accompanying it at all stages, ensuring monitoring and conducting an independent assessment to achieve social effect.

When the project is completed and an independent examination has confirmed the achieved social result, a grant in the form of a subsidy is paid to the private party. At the same time, independent auditors do not bear financial obligations under the contract. Most of the risks are borne by the investors, if they do not achieve the desired criteria, they lose their invested funds.

Entering the social bonds market became possible with the introduction of new Issue Standards from January 1, 2020, which reflects the basic principles of their issuance, use, requirements for early repayment in case of violation by the issuer of social financing goals, methods of control over the targeted use of funds, etc.

The first social impact project "Improving the educational results of students in the Republic of Sakha (Yakutia)" started in 2019 in the Republic of Sakha (Yakutia) within the framework of the national project "Education". A social effect is assumed to improve the educational process, thanks to which the regional secondary education system will be able to generate and implement various innovations, forming the necessary knowledge and competencies.

The project participants are: the organizer is the Far East and Arctic Development Fund, the executor (investor) is the National Research University Higher School of Economics, the customer is the Ministry of Education and Science of the Republic of Sakha (Yakutia). The organizer allocated 60 million rubles for the project. If the effect is achieved in 2022, the customer will pay 68 million rubles to the organizer in the form of a grant (subsidy) [2]. 
It is proposed to adapt the Regulation on pilot testing of social impact projects to the possibilities of circulation of social bonds in concession agreements in the field of water supply and sanitation of the Rostov region.

In Rostov oblast, as of January 1, 2020, 82 public-private partnership projects (concession agreements, projects «Quasi-PPP») with an investment volume of over 43.0 billion rubles were implemented. Most of the projects are implemented in the field of housing and communal services, where the construction and repair of water supply and sanitation facilities accounts for $27 \%$ of projects. On the investment portal of the region, it is possible to see more than 120 objects of water supply and sewerage networks, which are considered by the government as potential objects for PPP conclusion and concessions [4].

The proposed objects vary in scale, mostly small objects in cities and settlements of the region, which does not arouse business interest. PPP is a large or combined investor. Therefore, it is advisable to combine the projects for the modernization of sewerage and water supply into large pools so that the principles of public-private partnership can be used. In the Rostov region, all projects in this area are implemented in the form of a concession. It was the concession that began to practically embody debt obligations as additional financing instruments. Certain exceptions apply to the issuance of concession bonds. So, in 2008 by the Order FFMS the list of exceptional cases was expanded when securities can be included in quotation lists without fulfilling the special requirements required for issue in the usual manner. Such a requirement was the provision that the concessionaire should issue bonds. In 2018, 33 bond issues were allowed by 13 concessionaires in the amount of 100.9 billion rub. 28 issues of concession bonds of 11 issuers in the amount of 78.4 billion rubles are circulating on the exchange [1, p.18].

The traditional version of the issue and use of concession bonds is simplified as follows. The concessionaire issues bonds backed by the investor's future earnings. Funds from these bonds' sale are directed to the project implementation. Protection against all kinds of risks is also created through the use of a direct agreement. In the relationship between the private and public parties, a new participant arises - a financial institution that encloses all cash flows. A direct agreement defines the rights and responsibilities of the parties and links the implementation with the financing agreement execution.

In a direct agreement, the rights of a private investor are used as collateral to secure the claims of creditors. It allows attracting investment resources to the project, providing creditors as security with their rights to future revenues from the state (depending on the specifics of the financial model of the project).

Within the framework of the existing mechanism of circulation of concession bonds, the issue of social bonds can also be provided. But it is important to clearly define the social effect and social beneficiaries (recipients) of the effect for this. According to the International Capital Markets Association (ICMA), one of the goals of social performance projects can be to create accessible basic infrastructure (e.g., providing the population with clean drinking water, wastewater treatment, etc.) [12].

Municipal and regional water supply and sanitation projects fall into this category. If some of them are combined into one large object, it is possible to calculate its social impact on specific territories by means of quantitative indicators and identify a group of recipients of this impact.

The social effect of the modernization of the water supply and sanitation system will be the provision of the population and business entities with centralized water supply (80-90\% of the inhabitants of the settlement), improvement of drinking water quality, and uninterrupted water supply. In general, the project will contribute to improving the living conditions of the municipalities' population. This means that the beneficiaries can be considered as the groups of population that do not have sufficient access to services that 
ensure livelihoods. From this point of view, the circulation of such debt instruments of concessions can be identified as social bonds.

When choosing the type of social bond for such projects, it is advisable to use a standard debt obligation with the right to claim against the issuer, where future income from the customer in the form of a grant serves as collateral. The scheme of the interaction of the participants may look like in Figure 1.

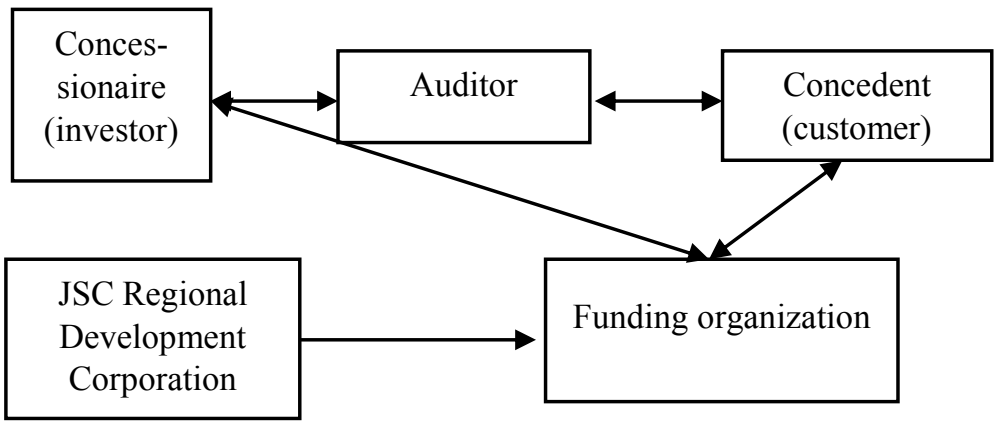

Fig. 1. The mechanism of circulation of social bonds, taking into account the activities of the Guarantee Fund (JSC "Regional Development Corporation") (compiled by the author)

The customer of the concession project is the concedent (regional authorities). The executor of the project is a concessionaire. By the agreement between them, a financial organization, which encloses all incoming cash flows of a private partner, which issues bonds, including social bonds, is created. The issuer of social bonds clearly formulates to the customer the social effects for the development of these territories with the criteria and indicators of their achievement.

Upon the project completion, it is imperative to conduct an independent audit assessment for the compliance of the achieved results with the declared social indicators of the project. Based on the results of an independent external examination, the customer (state authorities) decides on the grant payment to the investor.

Since the return of the invested funds is possible only upon successful completion of the project, which increases the investor's risks, it is advisable to involve another party who will support the project, provide consulting services, if necessary, and reduce the investor's risks. We are talking about creating a guarantee fund that limits risks and obliges to pay compensation (slightly less than the invested amount) regardless of the result under certain conditions, for example, with poorly predictable external shocks. Who can act as such a guarantor in the region? Regional development institutions, guarantee funds to support small and medium-sized businesses. In the Rostov region it is JSC Regional Development Corporation, which can provide guarantees for concession and PPP-projects.

This will increase the liquidity of social bonds, which in their essence do not yet have all the signs of debt obligations traded on the stock market. They will also require changes in the regulatory framework for exceptional cases in which securities can be included in quotation lists without fulfilling special requirements.

\section{Conclusion}

The need for technological modernization of HCS production infrastructure caused the use of various forms of public-private partnership. In the area of wastewater disposal and water supply at the local level, attracting large investors is very problematic. Therefore, new approaches are needed to stimulate the private party PPP, on the one hand, and the creation 
of new forms of relationship between government and business, capable of ensuring the territorial solution of specific social problems.

It is proposed to use a new financial instrument - social bonds. Funds from their placement are used to finance new or already implemented social projects that comply with the principles of social bonds. It is imperative to use the funds from their placement for the society development, it is important that the selection meets the criteria for social impact projects, so that an independent examination assesses the degree of achievement of the stated social goals, etc.

The projects under consideration should be aimed at solving a specific social problem; positive social results should be quantified. It is advisable to define the target group of social beneficiaries. Bond payments are made by the government if the investor achieves fixed social goals. If the goals are not met, the income is not paid.

The use of social bonds became possible In Russia after the release of the Government Decree "On the organization of pilot testing by the constituent entities of the Russian Federation in 2019 - 2024 of social impact projects" and the introduction of new Emission Standards from January 1, 2020, which reflects the basic principles of their issuance, use, requirements for early repayment in case of violation by the issuer of the social goals of financing, methods of control over the targeted use of funds, etc.

The first project was the social impact project "Improving the educational results of students in the Republic of Sakha (Yakutia)" in 2019 in the Republic of Sakha (Yakutia) within the framework of the national project "Education". The project participants are: the organizer is the Far East and Arctic Development Fund, the executor (investor) is the National Research University Higher School of Economics, the customer is the Ministry of Education and Science of the Republic of Sakha (Yakutia). The organizer allocated 60 million rubles for the project. If the effect is achieved in 2022, the customer will pay 68 million rubles to the organizer. in the form of a grant (subsidy). This is the first practical experience of using social bonds in the country.

It is proposed to adapt the Regulation on pilot testing of social impact projects to the possibilities of circulation of social bonds in concession agreements in the field of water supply and sanitation of the Rostov region. This is due to the fact that the dilapidated water supply and sewerage system of small towns and settlements needs large-scale renovation, which requires significant investments. Mechanism use PPP assumes large-scale volumes; therefore, municipal facilities are of little interest for business. To create a concession, several objects should be combined into a large project, and then the process of bonds circulation should be launched: concession, project, infrastructure.

Concession bonds by order FFMS was allowed to be included in quotation lists without fulfilling the special requirements required for the issue in the usual manner. The usual version of the issue and the concession bonds use is simplified as follows: the concessionaire issues bonds secured by the investor's future income. Funds from the sale of these bonds are directed to the project implementation. Protection against all kinds of risks is also created through the use of a direct agreement. In the relationship between the private and public parties, a new participant arises - a financial institution that encloses all cash flows. A direct agreement defines the rights and responsibilities of the parties and links the implementation with the execution of the financing agreement. In a direct agreement, the rights of a private investor are used as collateral to secure the claims of creditors. It allows attracting investment resources to the project, providing creditors as security with their rights to future revenues from the state.

Within the framework of this mechanism, the issue of social bonds can also be provided. But for this it is necessary to determine the social effect and social beneficiaries (recipients) of the effect. According to the International Capital Markets Association (ICMA), one of the social performance projects' goalscan be to create accessible basic 
infrastructure (e.g., providing the population with clean drinking water, wastewater treatment, etc.).

Municipal and regional water supply and sanitation projects fall into this category. If some of them are combined into one large object, it is possible to calculate its social impact on specific territories by means of quantitative indicators and identify a group of recipients of this impact.

The social effect of the water supply and sanitation system modernization will be the provision of the population and business entities with centralized water supply (80-90\% of the inhabitants of the settlement), drinking water quality improvement, as well as constant water supply. In general, the project will contribute to improving the living conditions of the population of municipalities. This means that the beneficiaries can be considered groups of the population that do not have sufficient access to services that ensure livelihoods. From this point of view, the circulation of such debt instruments of concessions can be identified as social bonds.

When choosing the type of social bond for such projects, it is advisable to use a standard debt obligation with the right to claim against the issuer, where future income from the customer in the form of a grant serves as collateral.

The concession project customer is the coincident (regional authorities). The executor of the project is a concessionaire. By agreement between them, a financial organization, which encloses all incoming cash flows of a private partner, which issues bonds, including social bonds, is organized. The issuer of social bonds clearly formulates the social effects for the development of these territories with criteria and indicators of their achievement to the customer.

The result will be an independent audit assessment of the social effects from the implementation of this project, on the basis of the findings of which the customer (state authorities) decides on the grant payment to the investor.

\section{Conclusion}

Since the investment return is possible only upon successful project completion, which increases the investor's risks, it is advisable to involve another participant who will accompany the project and advise in order to reduce the investor's risks. A guarantee fund that pledges to pay compensation (slightly less than the amount invested) regardless of the result under certain conditions, for example, with poorly predictable external shocks, should be created. Such guarantors in the region can be the regional development institutions, guarantee funds to support small and medium-sized businesses. In the Rostov region it is JSC Regional Development Corporation, which can provide guarantees for concession and PPP-projects.

This will increase the liquidity of social bonds, which in their essence do not yet have all the signs of debt obligations traded on the stock market. They will also require changes in the regulatory framework for exceptional cases in which the securities can be included in quotation lists without fulfilling special requirements.

\section{References}

1. Public-Private Partnership as a Mechanism for Financing Regional Infrastructure Projects in the Russian Federation: Current Situation, Challenges and Prospects. Expert Council on the Long-Term Infrastructure Investment Market at the Bank of Russia, Project Finance Working Group, 2019. 
2. VIS Group: a new issuer with a rating A Cbonds Review 4 (2020). [Electronic resource]. URL: http://review.cbonds.info/article/magazines/5379/ (application date: 12.03.2021).

3. N.V. Ivanova, Civil society in Russia and abroad 2, 8-11 (2015).

4. Information on agreements in the PPP field. Investment portal of Rostov oblast [Electronic resource]. URL: http://invest-don.com/ru/

5. N.V. Kalinin, T.V. Medvedeva, G.A. Romitsyna, International research Journal 2 (68), 53-56 (2017).

6. S.V. Kovrigina, PPP mechanism use problems for the production of public and quasipublic goods on the example of projects in the HCS field, Proceedings of the IX International Winter School on Institutional Economics. Sessions reports of the IX International Winter School on Institutional Economics, Yekaterinburg: Institute of Economics of the Ural Branch of the Russian Academy of Sciences, 2016.

7. S.V. Kozlova, O.M. Gribanova, Bulletin of the Institute of Economics of the Russian Academy of Sciences 4, 176-184 (2014).

8. K.I. Kryukova, A.A. Petrosyan, M.V. Chernishova, Science and education, 2016.

9. L.V. Naumova, Finance 02, $62-64$ (2017).

10. S.E. Petyukov, Innovation and investment 4, 31-34 (2017).

11. Government Decree No. 1491 of November 21, 2019 "On the organization of pilot testing of social impact projects by the constituent entities of the Russian Federation in 2019-2024." [Electronic resource]. URL: https://вэб.pф/ustojchivoe-razvitie/socialnoefinansirovanie/veb-i-socialnoe-finansirovanie// (applicationdate: 07.08.2020).

12. Principles of social bonds. Voluntary procedural guidelines. June 2020. Russian language translation courtesy of [VEB.RF] and reviewed by [RAEX-Europe] [Electronic resource]. URL: https://www.icmagroup.org/green-social-andsustainability-bonds/resource-centre//// (application date: 11.12.2020).

13. Elena Sidorenko, Vladislava Semiglazova, IOP Conference Series: Materials Science and Engineering. https://iopscience.iop.org/article/10.1088/1757-899X/913/5/052012

14. D.E. Khulukshinov, E.V. Savenkova, Economic and legal issues 6 (120), 75-78 (2018). 